\begin{tabular}{|c|c|c|}
\hline Dinamika Journal, Vol. 1 No. 4, 2019 \\
ISSN ONLINE : 2686-2158
\end{tabular}

\title{
PROSES PEMBUATAN GENTENG SOKKA KEBUMEN
}

\author{
Jamrud Aminuddin ${ }^{1 *}$, Aris Haryadi ${ }^{1)}$, Sunardi ${ }^{1)}$ \\ Jurusan Fisika, Fakultas Matematika dan Ilmu Pengetahuan Alam, Universitas Jenderal \\ Soedirman, Purwokerto, Indonesia \\ *Corresponding author: jamrud.aminuddin@unsoed.ac.id
}

Received 4 November 2019; Accepted 6 December 2019; Available online 11 December 2019

\begin{abstract}
Abstrak
Proses pembuatan genteng secara keseluruhan dilakukan dalam 4 tahapan utama. Proses tersebut dimulai dari pemilihan bahan baku genteng yang terdiri dari tanah liat dan pasir laut dengan perbandingan 4:1. Kedua bahan baku tersebut dicampur dengan air menggunakan mesin penggiling selama 1 hari. Setelah tercampur secara merata, campuran tersebut dikeringkan dengan angin kembali selama 1 hari sampai kental. Campuran tersebut dihaluskan kembali dengan mesin penggiling selama 1 hari, kemudian dianginkan selama 1 hari. Dari proses pencampuran terakhir, campuran tersebut dicetak dengan mesin press. Proses ini berlangsung selama kurang lebih 4 hari. Proses selanjutnya, genteng mentah yang sudah dicetak dikeringkan kembali dengan angin selama 10 hari. Setelah itu, dikeringkan di bawah sinar matahari selama 4 hari. Genteng kering tersebut disusun dalam tungku pembakaran kemudian dibakar dengan api kecil untuk menghilangkan uap air sekaligus pada bagian ini merupakan proses adaptasi panas pada material genteng. Proses ini dilakukan selama kurang lebih 4 hari. Proses terakhir adalah pembakaran dengan api besar untuk menghasilkan genteng matang. Proses terakhir ini berlangsung selama 2 hari diikuti proses pendinginan selama 2 hari. Jadi secara keseluruhan proses pembuatan genteng Sokka Kebumen biasanya dilakukan selama kurang lebih 30 hari.
\end{abstract}

Kata kunci: genteng, material, tungku, sokka

\begin{abstract}
Manufacturing process of roof-tile is wholly done in 4 main steps. The process start from choosing material of roof-tile that consist of clay and sand with ratio 4:1 (4 for clay and 1 for sand). Both of materials are mixed with water using cement mixer for about 1 day. After mixed, the compound is dried up with wind as long as 1 day up to thick. The thick compound is mixed again using cement mixer for 1 day, then it is dried up again by wind for 1 day. From the last mixing, The compound is molded using press machine. This process is carried out for around 4 days. The next process, the raw roof-tile which has been molded is dried up again by wind for about 10 days. Then, they are dried up under sunlight at least 4 days. The dried roof-tiles is arranged in the roof-tile stove, then it is burned using small fire to reduce water vapor and also this step is heat adaptation process to roof-tile material. This process is conducted for around 4 days. The final process is burning the roof-tile using large fire to obtain roof-tile mature. This final process is carried out for 2 days followed by cooling process for 2 days. Overall, Sokka-Kebumen roof-tile manufacturing process is conducted for around 30 days.
\end{abstract}

Keywords: roof-tile, material, stove, sokka 


\section{PENDAhULUAN}

Proses pembuatan genteng umumnya dilakukan melalui 4 (empat) tahapan utama, yaitu: pemilihan dan pencampuran material, pencetakan, pengeringan dengan angin dan sinar matahari, dan pembakaran dalam tungku dan penghalusan genteng. Keempat proses utama tersebut biasanya dilakukan oleh pengajin genteng yang sudah berpengalaman. Pada proses pembuatan sekitar 20.000, bagi para pengusaha genteng yang sudah mempunyai tenaga berpengalaman mampu menghasilkan sekitar $\pm 95 \%$ genteng dengan kualitas standar. Dalam hal ini hanya ada $\pm 5 \%$. genteng yang cacat. Dilain pihak bagi para pengusaha yang belum mempunyai tenaga berpengalaman, genteng yang dihasilkan $\pm 75 \%$ dengan kualitas standar dan $\pm 25 \%$ lainnya dengan kualitas dibawah standar (tidak simetris, blonteng, retak sebagian dan pecah).

Solusi yang ditawarkan untuk permasalahan tersebut adalah menyusun petunjuk praktis dalam tentang bagaimana memproduksi genteng yang berkualitas. Standar kualitas dalam kegiatan yang dilakukan hanya dilakukan secara kualitatif. Sebuah genteng disebut berkualitas ketika tidak mudah pecah. Berdasarkan wawancara langsung, penelitian sebelumnya, dan beberapa referensi, diketahui bahwa keempat tahapan utama dalam proses pembuatan genteng yang telah disebutkan merupakan proses yang pada prinsipnya dapat diukur dengan besaran yang sifatnya populer dikalangan pengrajin. Besaran tersebut merupakan representasi besaran fisika yang dinyatakan dalam bentuk yang mudah dipahami pengrajin (Haryadi et al., 2007).

Kajian ilmiah terkait keempat proses utama dalam pembuatan genteng telah dilakukan beberapa peneliti sebelumnya. Proses paling awal adalah pemilihan dan pencampuran material genteng. Material genteng tersusun atas tiga bahan utama, yaitu: tanah liat, pasir halus sebagai bahan campuran, dan air sebagai bahan pelebur. Ketiga material dasar penyusun genteng tersebut diolah dengan perbandingan tertentu untuk menghasilkan tanah yang bagus tidak terlau keras juga tidak terlau lembek (Musabbikhah, 2007; Sriyatun et al., 2013). Proses berikutnya adalah pencetakan. Material genteng yang sudah dihaluskankan dicetak melalui mesin press. Pada proses pencetakan genteng akan dihasilkan berbagai jenis bentuk tergantung pada model cetakan, seperti genteng biasa bulat, genteng biasa papak, Morando, Mantili, Kerpus bulat, dan Kerpus Papak (Amin dan Irawan, 2010). Selanjutnya genteng mentah yang dihasilkan dari proses pencetakan dikeringkan kemudian dijemur dibawah sinar matahari (Haryadi et al., 2007). Proses terakhir dalam pembuatan genteng adalah pembakaran. Dari hasil penelitian yang telah dilakukan dapat diperkirakan bahwa pada 20.000 keping genteng diperlukan waktu pembakaran selama 6 hari, 4 hari untuk pengasapan dengan tujuan adaptasi panas serta menghilangkan uap air yang tersisa, dan 2 hari untuk mematangkan genteng sedangkan proses pendinginan selama 2 hari (Haryadi et al., 2007). Berdasarkan pengamatan langsung yang telah dilakukan sebelumnya, juga diketahui bahwa bagian paling penting setelah pembakaran adalah penghalusan genteng matang untuk meningkatkan kualitas dan nilai jual genteng. Proses penghalusan dapat dilakukan dengan cara mengikir bagian yang belum rata dilanjutkan dengan pengecatan bagian luar genteng.

\section{METODE PELAKSANAAN}

Proses pembuatan genteng dalam jumlah yang besar $( \pm 30.000$ keping $)$ dapat dilakukan dalam waktu \pm 30 hari. Hal ini diketahui dari hasil pengamatan dan wawancara dengan pengrajin genteng sokka di Desa Jabres, Kecamatan Sruweng, Provinsi Jawa Tengah. Proses pembuatan genteng dilakukan melalui 4 tahapan utama. Pada tahap awal yaitu pemilihan dan pencampuran awal material atau bahan baku genteng dilakukan selama \pm 4 hari. Proses selanjutnya adalah pencetakan genteng mentah yang dapat dilakukan selama \pm 4 hari. Selanjutnya proses pengeringan dengan angin dapat dilakukan selama \pm 10 hari dan dengan penjemuran di bawah sinar matahari dapat dilakukan selama \pm 4 hari. Proses terakhir adalah 
pembakaran dengan api kecil dilakukan selama \pm 4 hari dan dengan api besar dilakukan selama \pm 2 hari. Sedangkan proses pendinginan dilakukan selama \pm 2 hari. Untuk meningkatkan mutu atau harga jual genteng proses yang perlu dilakukan setelah proses pembuatan genteng adalah penghalusan. Tahapan lengkap tentang cara pembuatan genteng diuraikan pada bagian berikutnya dalam tulisan ini.

\section{HASIL DAN PEMBAHASAN}

Pada bagian ini akan diuraikan secara lengkap tahapan dan cara pembuatan genteng yang diproduksi di Sokka-Kebumen, Jawa Tengah. Proses pembuatan genteng secara keseluruhan dilakukan dalam 4 tahapan utama. Secara keseluruhan proses pembuatan genteng Sokka Kebumen biasanya dilakukan selama kurang lebih 30 hari.

\subsection{Pemilihan dan pencampuran material}

Material atau bahan baku untuk membuat genteng terdiri atas tanah liat dan pasir laut dengan perbandingan 4:1 (4 takaran tanah liat dan 1 takaran pasir laut). Pada proses pembuatan genteng dalam jumlah yang banyak biasanya digunakan mobil bak sebagai takaran. Material genteng diperlihatkan pada Gambar 1.

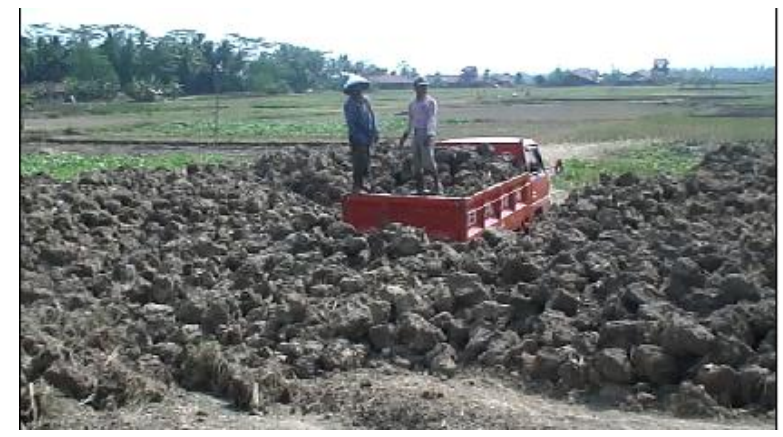

a) tanah liat

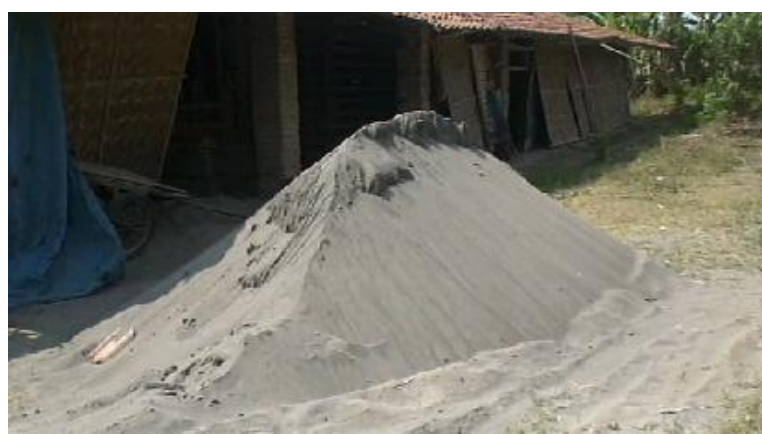

b) pasir laut

Gambar 1. Material untuk membuat genteng

Proses pencampuran bahan baku genteng dilakukan melalui 2 tahapan. Pada tahap awal, bahan baku genteng yang terdiri atas tanah liat dan pasir laut dicampur dengan perbandingan 4:1 kemudian digiling dalam mesin molen sampai tercampur secara merata. Adonan bahan baku genteng yang telah tercampur secara merata tersebut dikeringkan dengan angin bukan dengan sinar matahari sehingga adonan yang dihasilkan tidak terlalu kering, tetapi kental. Proses pecampuran hingga mendapatkan adonan yang kental biasanya dilakukan 1 sampai 2 hari tergantung kondisi cuaca. Pada Gambar 2 diperlihatkan proses pencampuran material genteng dengan menggunakan mesin penggiling atau molen. Bentuk adonan genteng kental yang dihasilkan pada pencampuran tahap awal diperlihatkan pada Gambar 3. Tahap selanjutnya adalah penghalusan adonan genteng dengan menggunakan mesin penggiling (Gambar 4). Pada proses ini adonan yang sudah halus dicetak dalam bentuk segiempat. Adonan tersebut selanjutnya dikeringkan selama 1 sampai 2 hari bergantung pada kondisi cuaca. Bentuk Adonan tersebut diperlihatkan pada Gambar 5. 


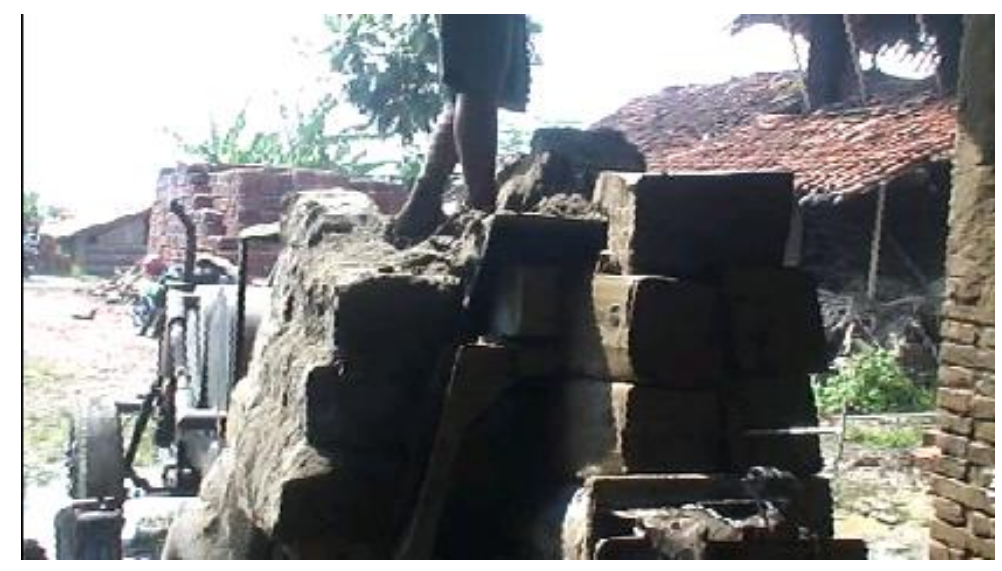

Gambar 2. Proses pencampuran material genteng

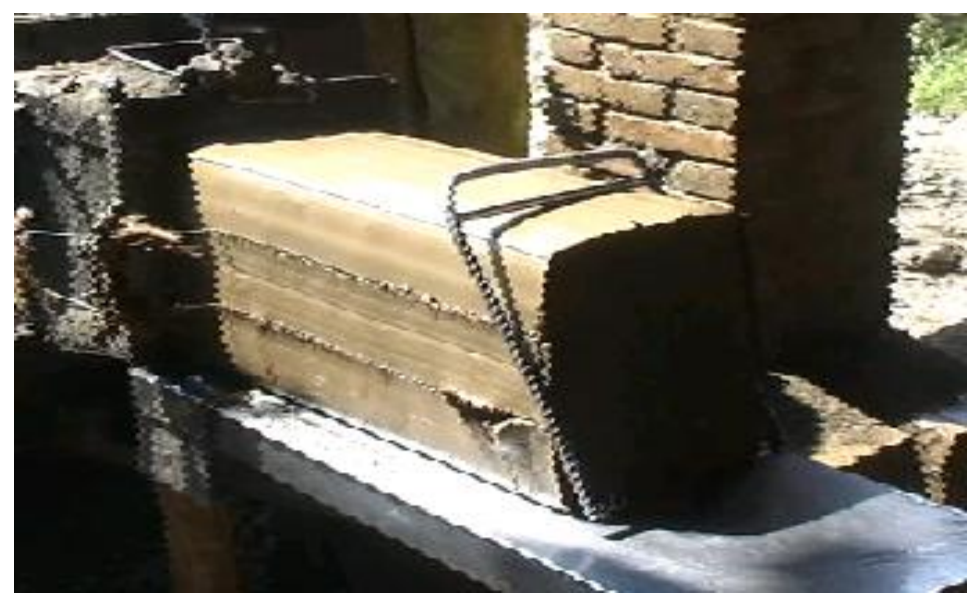

Gambar 3. Hasil pencampuran awal material genteng

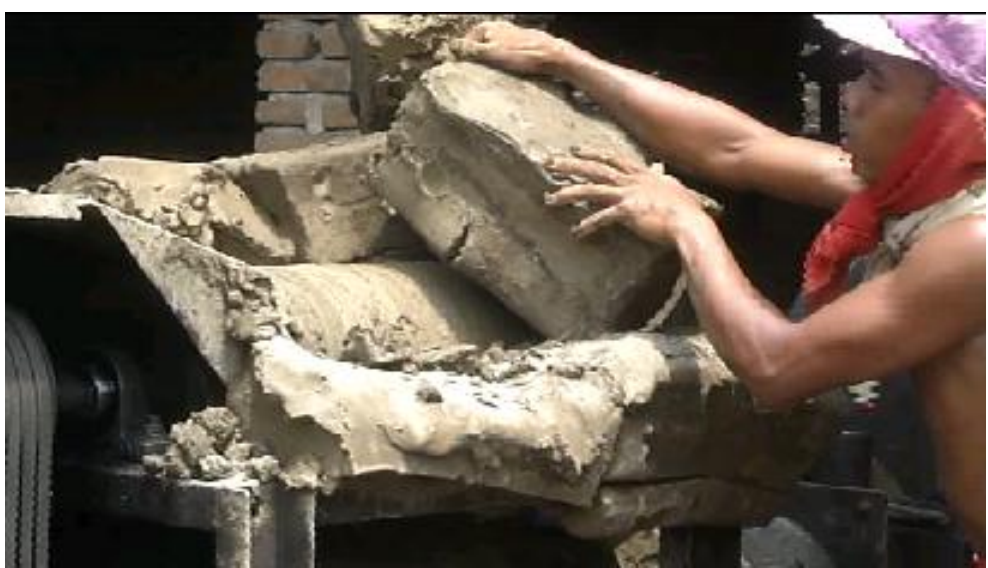

Gambar 4. Proses penghalusan material genteng 


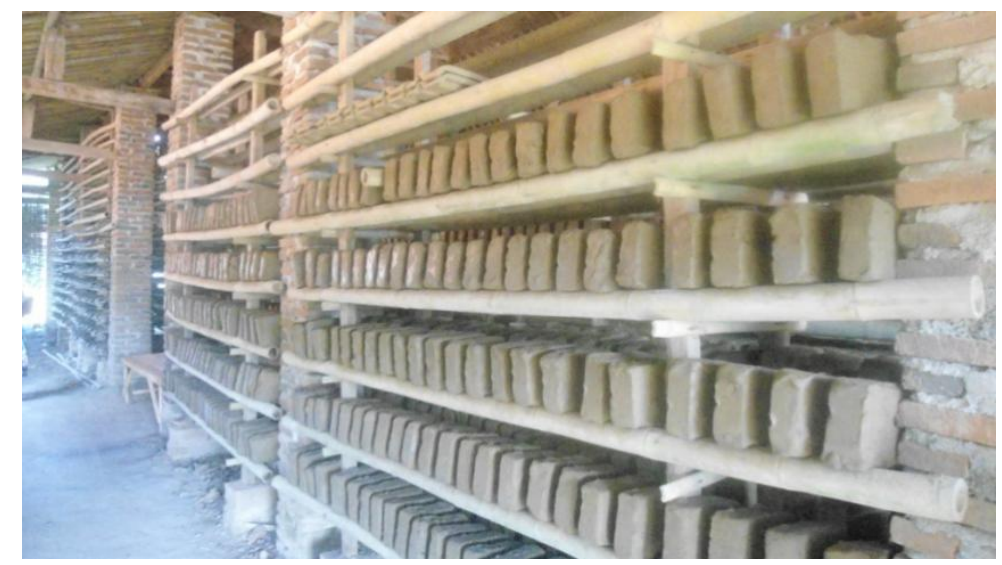

Gambar 5. Material genteng yang siap dicetak

\subsection{Pencetakan genteng}

Proses selanjutnya adalah pencetakan genteng. Proses ini dilakukan dengan menggunakan mesin press bergantung pada model genteng yang diinginkan. Salah satu bentuk mesin press diperlihatkan pada Gambar 6. Proses pencetakan dapat dilakukan dalam 3 (tiga) tahapan, yaitu: pemadatan, pencetakan, dan penghalusan. Proses awal yang dilakukan dalam pencetakan adalah pemadatan dengan cara di pukul dengan pemukul yang sesuai dengan bahan atau adonan genteng yang siap dicetak menggunakan mesin press. Sebelum dimasukkan kedalam mesin press, adonan genteng yang siap dicetak diolesi minyak pelumas kemudian di cetak kemudian dikeluarkan dari mesin press. Tahapan akhir dari proses pencetakan adalah penghalusan. Proses ini dilakukan untuk membersihkan sisa campuran yang melekat pada genteng setelah proses pencetakan dalam mesin press. Banyaknya genteng yang dihasilkan pada proses ini bergantung pada kemampuan pekerja. Secara keseluruhan, proses pencetakan dilakukan selama \pm 4 hari atau bergantung pada kemampuan pekerja. Gambaran singkat proses ini diperlihatkan pada Gambar 7.

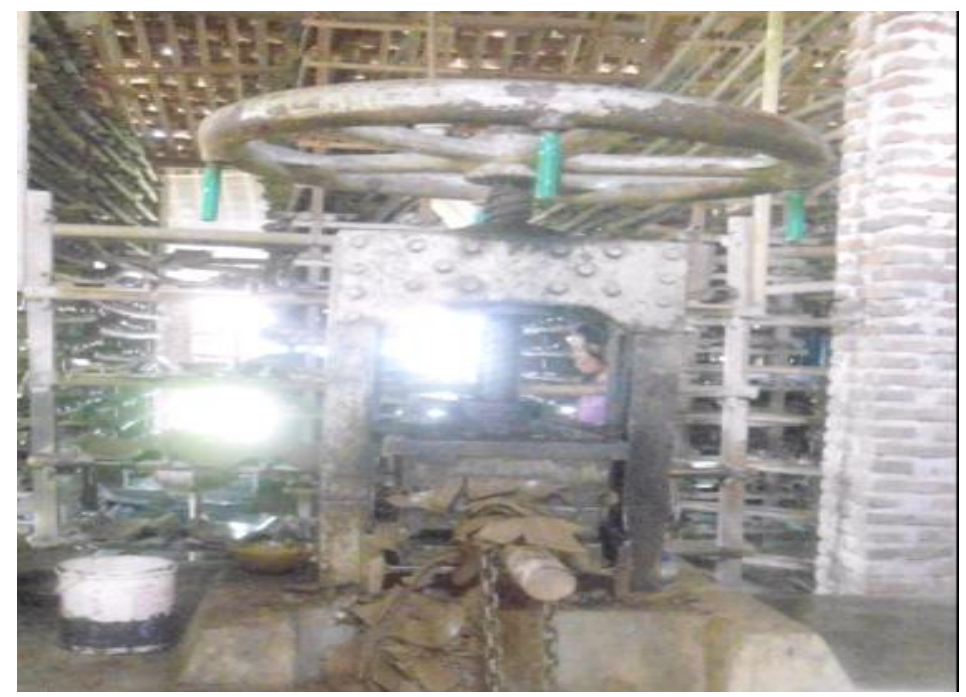

Gambar 6. Mesin pencetak genteng 


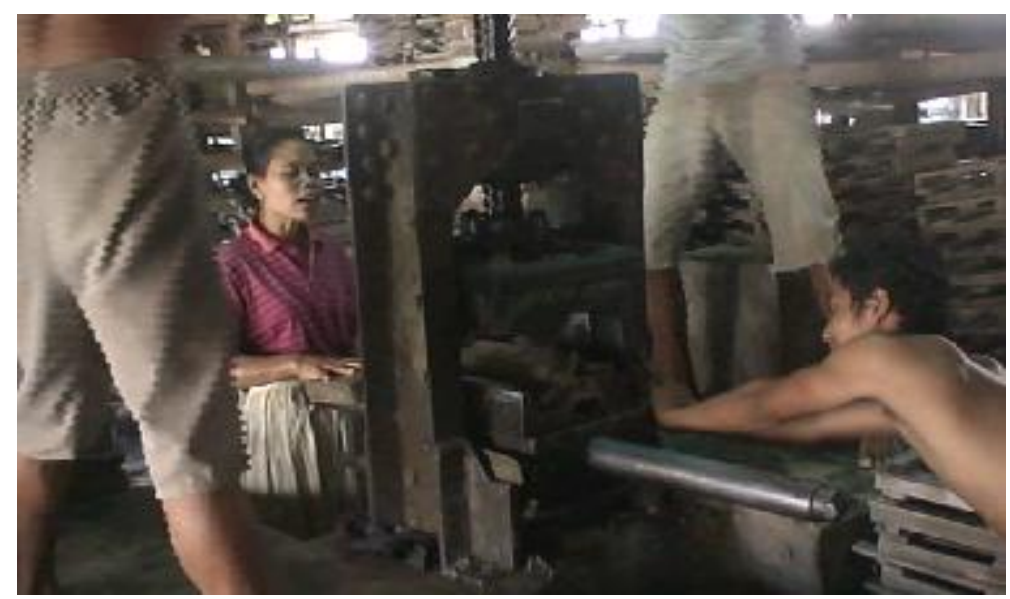

Gambar 7. Proses pencetakan genteng

\subsection{Pengeringan genteng}

Proses pengeringan genteng yang sudah dicetak dilakukan dalam 2 tahapan utama. Pada tahap awal, genteng mentah yang dihasilkan pada proses pencetakan diletakkan pada posisi terlentang di atas rak untuk dikeringkan kembali dengan angin selama \pm 10 hari. Proses selanjutnya adalah genteng yang sudah dikeringkan dengan angin, dikeringkan kembali di bawah sinar matahari atau dijemur selama \pm 4 hari. Gambaran singkat proses pengeringan dengan angin dan sinar matahri diperlihatkan pada Gambar 8 dan Gambar 9.

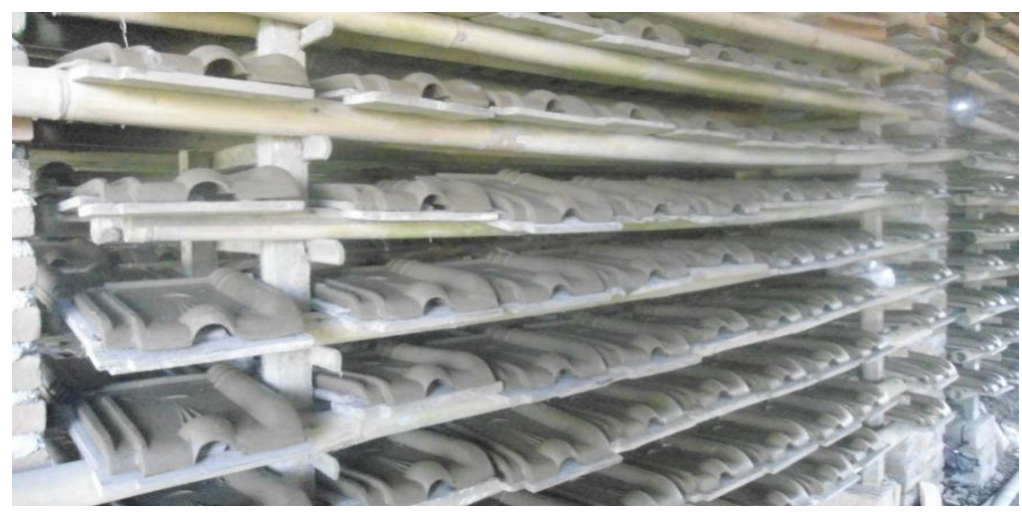

Gambar 8. Proses pengeringan genteng dengan angin

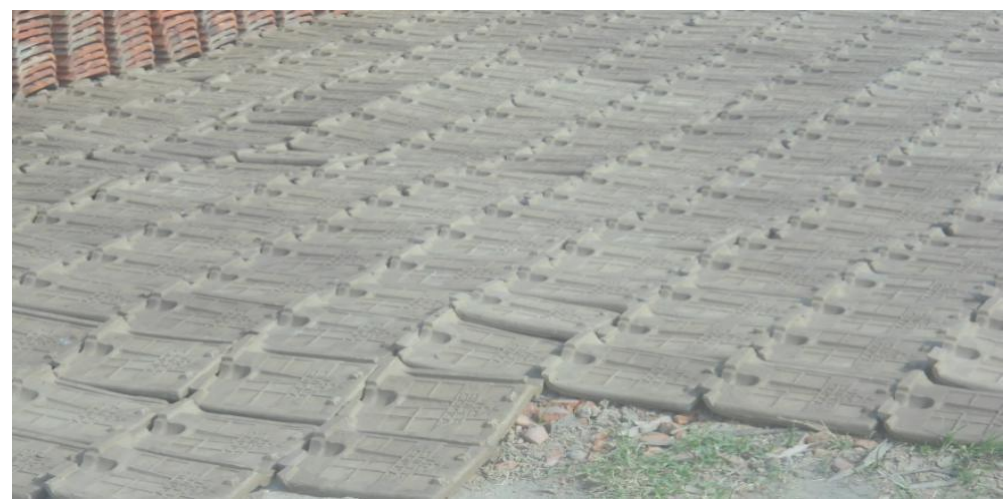

Gambar 9. Proses penjemuran di bawah sinar matahari 


\subsection{Pembakaran genteng}

Pada proses pembakaran genteng dilakukan dalam 4 tahapan utama, yaitu: penyusunan genteng dalam tungku, pengasapan, pembakaran, dan pendinginan. Pada tahap awal, genteng yang sudah dijemur di bawah sinar matahari disusun dalam tungku pembakaran (tobong). Tahap selanjutnya adalah pengasapan atau pembakaran dengan api kecil. Pembakaran dengan api kecil dilakukan untuk menghilangkan uap air sekaligus merupakan proses adaptasi panas pada material genteng mentah selama \pm 4 hari. Proses selanjutnya adalah pembakaran dengan api besar untuk menghasilkan genteng matang selama \pm 2 hari. Proses terakhir dalam proses ini adalah pendinginan selama \pm 2 hari. Gambaran singkat mengenai tahapan pembakaran genteng diperlihatkan pada Gambar 10, 11, dan 12 . Pada Gambar 13 juga diperlihatkan beberapa model genteng yang telah diproduksi oleh pengrajin Genteng Sokka di Desa Jabres, Kecamatan Sruweng, Kabupaten Kebumen, Provinsi Jawa Tengah.

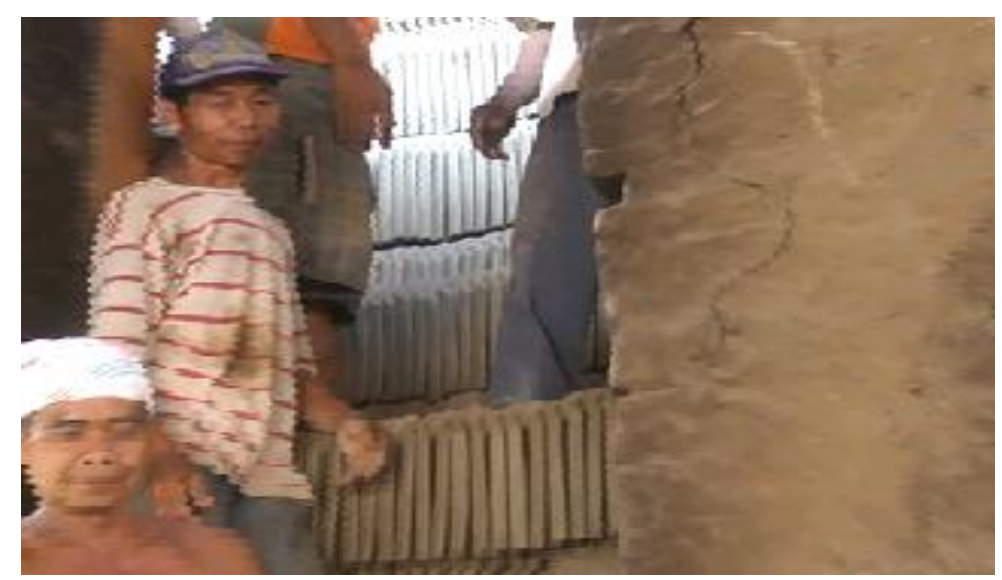

Gambar 10. Proses penyusunan genteng dalam tobong

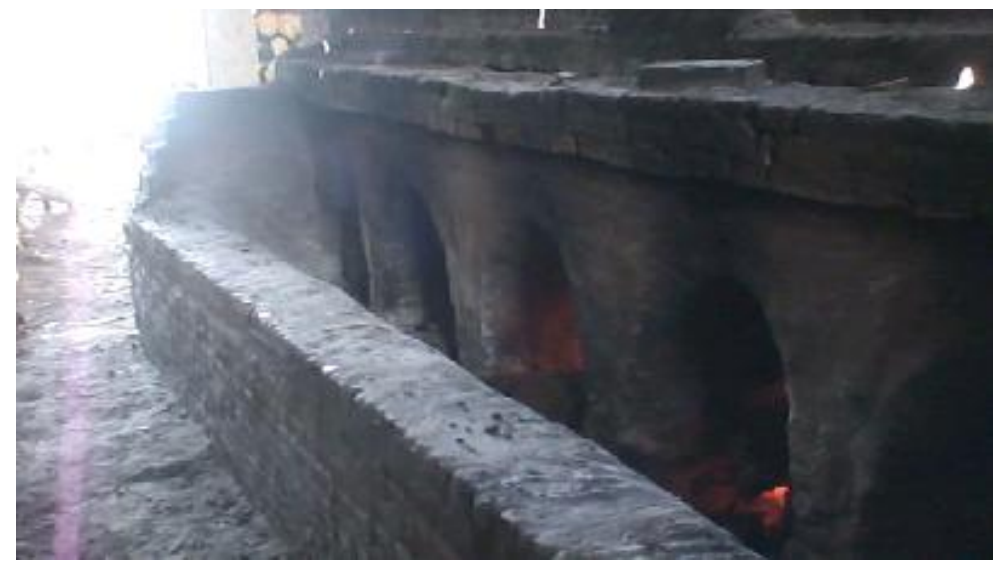

Gambar 11. Proses pengasapan genteng dengan api kecil 


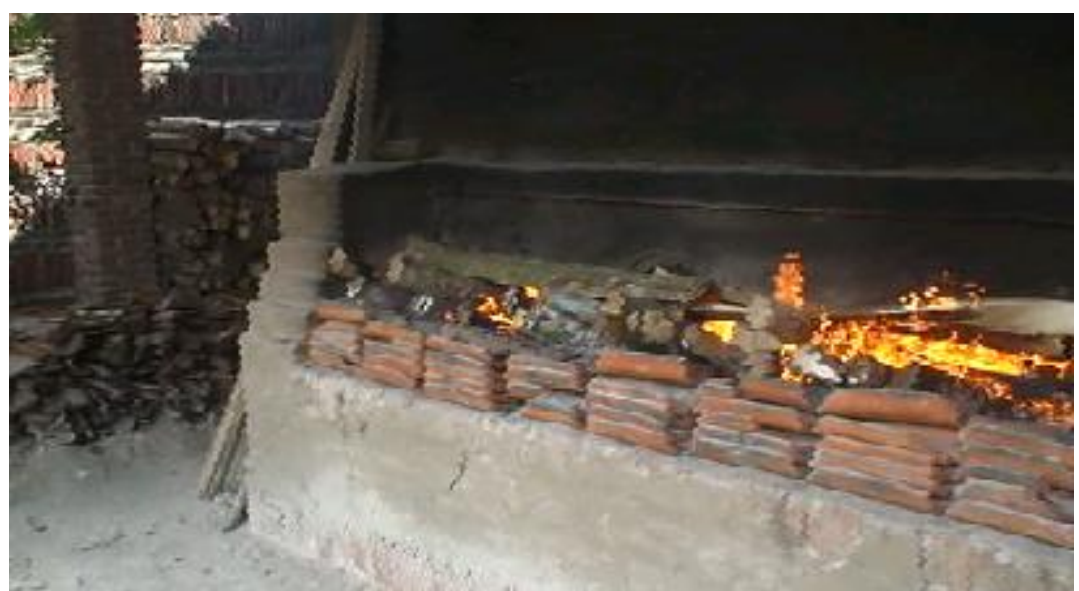

Gambar 12. Proses pembakaran genteng dengan api besar

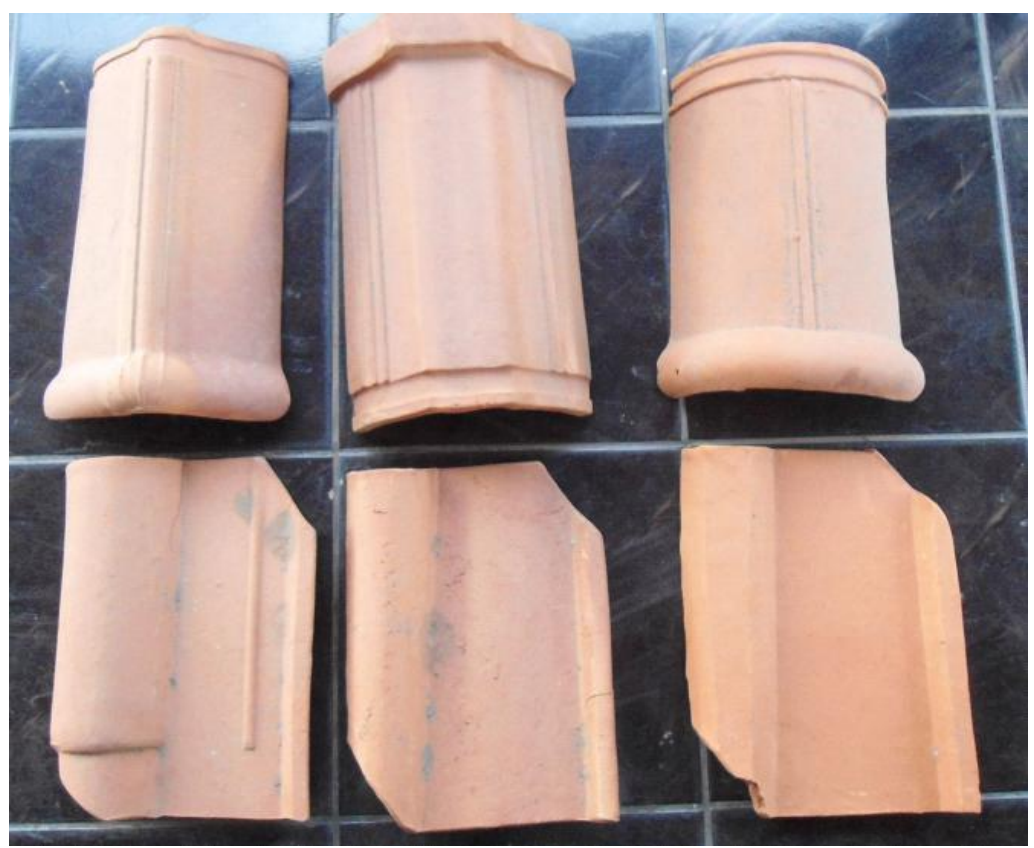

Gambar 13. Beberapa model genteng

Setelah proses akhir pembuatan genteng, dapat dilakukan beberapa tahapan penting untuk meningkatkan mutu atau harga jual genteng. Berdasarkan wawancara dan pengamatan langsung yang telah dilakukan, diketahui bahwa bagian paling penting setelah proses pembuatan genteng adalah penghalusan. Proses penghalusan dapat dilakukan dengan cara mengikir bagian yang belum rata dilanjutkan dengan pengecatan bagian luar genteng.

\section{KESIMPULAN}

Proses pembuatan genteng yang biasanya dilakukan oleh pengusaha genteng Sokka dilakukan selama \pm 30 hari. Proses tersebut dimulai dari pemilihan bahan baku genteng yang terdiri dari tanah liat dan pasir laut. Hasil campuran material dicetak dengan mesin press berdasarkan model genteng yang diinginkan. Tahapan berikutnya adalah pengeringan dengan angin dan sinar matahari. Genteng yang sudah kering selanjutnya dibakar dalam tungku pembakaran. 


\section{UCAPAN TERIMA KASIH}

Kami ucapkan terima kasih kepada penyandang dana kegiatan yang telah saya laksanakan hingga artikel ini telah berhasil dituliskan. Kegiatan ini dilaksanakan atas biaya dari LPPM UNSOED pada skim pengabdian audiovisualisasi IPTEKS Tahun Anggaran 2014 dengan Nomor Kontrak: DIPA-023.04.2.1.189899/2014 Tanggal 5 Desember 2013 dan Nomor Surat Perjanjian : 2244/UN23.10/PM/2014.

\section{DAFTAR PUSTAKA}

Amin, M dan B. Irawan. 2010. Pengaruh Tekanan Kompaksi dan Suhu Sintering Terhadap Kekerasan Keramik Lumpur Lapindo. Prosiding Seminar Nasional UNIMUS: 290-295.

Haryadi A, J. Aminuddin, dan Sunardi. 2007. Optimasi Pembakaran Genteng Melalui Analisis Perambatan Panas dengan Metode Beda Hingga. Jurnal Inovasi, Unsoed, Vol 1, No. 1.

Musabbikhah, P. S, 2007. Variasi Komposisi Bahan Genteng Sokka Untuk Mendapatkan Daya Serap Air Yang Optimal. Jurnal Media mesin, Vol. 8, No. 2: 59-64.

Sriatun, A. Yulianto, dan Sulhadi. 2013. Analisis Sifat Mekanik Genteng Keramik Hasil Campuran Lumpur Lapindo, Unnes Physics Journal, Vol. 2, No. 1: 58-64. 